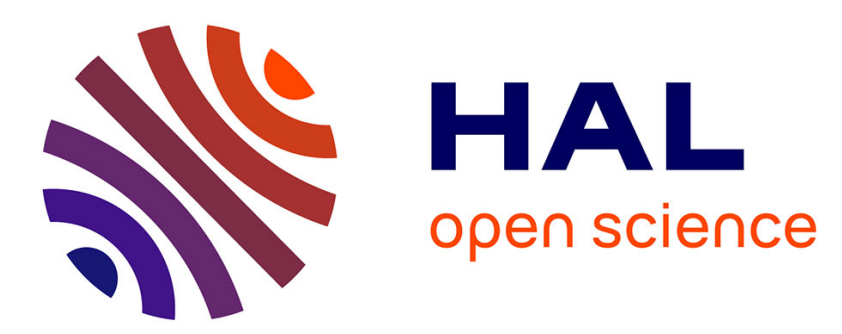

\title{
Bacterial immobilization and oxidation of arsenic in acid mine drainage (Carnoulès creek, France)
}

Corinne Casiot, Guillaume Morin, Farid Juillot, Odile Bruneel, Jean-Christian

Personné, Marc Leblanc, Katia Duquesne, Violaine Bonnefoy, Françoise

Elbaz-Poulichet

\section{To cite this version:}

Corinne Casiot, Guillaume Morin, Farid Juillot, Odile Bruneel, Jean-Christian Personné, et al.. Bacterial immobilization and oxidation of arsenic in acid mine drainage (Carnoulès creek, France). Water Research, 2003, 37 (12), pp.2929-2936. 10.1016/S0043-1354(03)00080-0 . hal-03533985

\section{HAL Id: hal-03533985 \\ https://hal.science/hal-03533985}

Submitted on 8 Feb 2022

HAL is a multi-disciplinary open access archive for the deposit and dissemination of scientific research documents, whether they are published or not. The documents may come from teaching and research institutions in France or abroad, or from public or private research centers.
L'archive ouverte pluridisciplinaire HAL, est destinée au dépôt et à la diffusion de documents scientifiques de niveau recherche, publiés ou non, émanant des établissements d'enseignement et de recherche français ou étrangers, des laboratoires publics ou privés. 


\title{
Bacterial immobilization and oxidation of arsenic in acid mine drainage (Carnoulès creek, France)
}

\author{
Corinne Casiot $^{\mathrm{a}, *}$, Guillaume Morin ${ }^{\mathrm{b}}$, Farid Juillot ${ }^{\mathrm{b}}$, Odile Bruneel ${ }^{\mathrm{a}}$, \\ Jean-Christian Personné ${ }^{\text {, Marc Leblanc }}{ }^{\mathrm{a}}$, Katia Duquesne ${ }^{\mathrm{c}}$, \\ Violaine Bonnefoy ${ }^{\mathrm{c}}$, Françoise Elbaz-Poulichet ${ }^{\mathrm{a}}$
}

${ }^{a}$ Laboratoire Hydrosciences Montpellier, UMR 5569, Université Montpellier 2, Place E. Bataillon, 34095 Montpellier cedex 05, France

${ }^{\mathrm{b}}$ Laboratoire de Minéralogie-Cristallographie, UMR CNRS 7590, Universités Paris 6 et 7, et IPGP, 4 Place Jussieu, 75252 Paris cedex 05, France

${ }^{\mathrm{c}}$ Laboratoire de Chimie Bactérienne UPR 9043, CNRS, 31 Chemin Joseph Aiguier, 13402 Marseille cedex 20, France

\begin{abstract}
The acid waters $(\mathrm{pH}=2.73-3.37)$ originating from the Carnoulès mine tailings contain high dissolved concentrations of arsenic $\left(1-3.5 \mathrm{mmoll}^{-1}\right)$ and iron $\left(20-40 \mathrm{mmoll}^{-1}\right)$. At the outlet, arsenite predominates. During the first $30 \mathrm{~m}$ of downflow, $20-60 \%$ is removed by coprecipitation with $\mathrm{Fe}(\mathrm{III})$. This process results from bacterially mediated As- and Fe-oxidation. The precipitation rates in the creek depend on the oxygen concentration in spring water and are lower during the dry summer period when the anoxic character of the spring water inhibits the activity of oxidizing bacteria. Ex situ experiments show that the presence of bacteria-rich precipitates increases the As- and Fe-removal rates. Three strains of bacteria promoting the oxidation of As have been isolated, and two of them have the characteristics of Thiomonas ynys1. The third strain, which is not identified yet, also catalyzes the oxidation of Fe.
\end{abstract}

Keywords: Arsenic; Oxidation; Bacteria; Acid mine drainage

\section{Introduction}

Arsenic is omnipresent in the Earth's crust, with a mean concentration of $3 \mathrm{mg} \mathrm{kg}^{-1}$ [1]. It is released to the biosphere through a combination of natural processes and human activities, such as the processing of sulfiderich ores to recover base metals (copper, lead, zinc, gold, etc.) which produces large quantities of As-rich wastes. When exposed to meteoric water, this material generates acid mine drainage characterized by elevated sulfate, arsenic and iron content. Because of the high As toxicity, numerous publications have been dedicated to its chemical behavior in natural systems [2-4] and in acid

\footnotetext{
*Corresponding author. Tel.: +33-4-67-14-33-56; fax: +334-67-14-47-74.

E-mail address: casiot@msem.univ-montp2.fr (C. Casiot).
}

mine drainage [5-7]. Arsenic mobility is limited by its ability to bind to many solid phases such as Fe oxides and to a lesser extent $\mathrm{Al}$ hydrous oxides [8,9]. In addition, Mn oxides are known for their capacity to oxidize As [10]. The affinity of As for these mineral surfaces strongly depends on its oxidation state. At acid $\mathrm{pH}$, arsenate $\left(\mathrm{H}_{2} \mathrm{AsO}_{4}^{-}\right)$adsorbs more strongly than arsenite $\left(\mathrm{H}_{3} \mathrm{AsO}_{3}\right)$ on $\mathrm{Fe}(\mathrm{III})$ (hydr)oxides [8,11]. Thus, changes in oxidation state strongly influence the mobility of As. The abiotic oxidation of As(III) is relatively slow [12] but it has been demonstrated, as already done for $\mathrm{Fe}$, that bacteria catalyze As oxidation $[13,14]$. Such bacteria have been isolated in acid hot springs [15,16] and mining effluents [17].

The objective of this paper was to present the chemical and microbial processes that influence As mobilization in the creek of Carnoulès (France), which 
drains pyrite-rich mine tailings. The distribution of redox As species in water has been determined, and the role of bacteria on As distribution and precipitation kinetics was investigated after isolation of some strains living in the local environment.

\section{Materials and methods}

\subsection{Site description}

Carnoulès is located in Southern France (Fig. 1) in the drainage basin of the Rhône river. The mining activity, stopped in 1962, has left about $1.5 \mathrm{Mt}$ of sulfidic wastes containing $0.7 \% \mathrm{~Pb}, 10 \% \mathrm{Fe}$ and $0.2 \%$ As [18]. These wastes are stored behind a dam, over a segment of the Reigous creek valley. The seepage water drained from the mine percolates through the tailings and is acid. It is collected by a draining pipe which has been buried under the tailings. It emerges at the basis of the dam, forming the spring of the Reigous creek and has a variable flow rate depending on meteoric conditions (see results). The mean annual rainfall is $1100 \mathrm{~mm}$, with a seasonal distribution typical of the Mediterranean climate, including long drought periods and intense precipitation events, especially in spring and autumn. The Reigous creek water contains high (up to $3.3 \mathrm{mmoll}^{-1}$ ) and variable As concentrations $[18,19]$. As-rich (up to $20 \%$ ) yellow sediments cover the bottom of the creek [18] and agglomerate along a small wall situated at $30 \mathrm{~m}$ from the outlet. These sediments have the stoichiometry of ferric arsenate $(\mathrm{Fe} / \mathrm{As}=1.5-2)$ [20]. The creek collects downstream seepage waters from the surroundings before joining, at $1.5 \mathrm{~km}$, the relatively pristine Amous river (Fig. 1).

\subsection{Sampling and analyses}

Water samples were collected during eight surveys carried out in 2001. The sampling stations (Fig. 1) are located over a relatively short distance $(40 \mathrm{~m})$, where no addition of seepage water is detected.

The main physicochemical parameters $\left(\mathrm{pH}, \mathrm{O}_{2}\right)$ were measured in the field. $\mathrm{pH}$ was measured with an Ultrameter ${ }^{\mathrm{TM}}$ Model 6P (Myron L Company, Camlab, Cambridge) equipped with a $\mathrm{pH}$ sensor. Dissolved $\mathrm{O}_{2}$ was measured with CHEMets ${ }^{\circledR}$ tests (CHEMetrics, Calverton, USA) based on colorimetric detection after reaction of $\mathrm{O}_{2}$ with indigo carmine for the range of $0-375 \mu \mathrm{M}$ and with rhodazine $\mathrm{D}$ for $0-30 \mu \mathrm{M}$. The detection limit is $3 \mu \mathrm{M}$.

Water samples were filtered immediately through $0.45 \mu \mathrm{m}$ Millipore membranes fitted on Sartorius polycarbonate filterholders. Samples for total $\mathrm{Fe}$ and As determination were acidified to $\mathrm{pH}=1$ with $\mathrm{HNO}_{3}$ $(14.5 \mathrm{M})$, and stored at $4^{\circ} \mathrm{C}$ in polyethylene bottles until

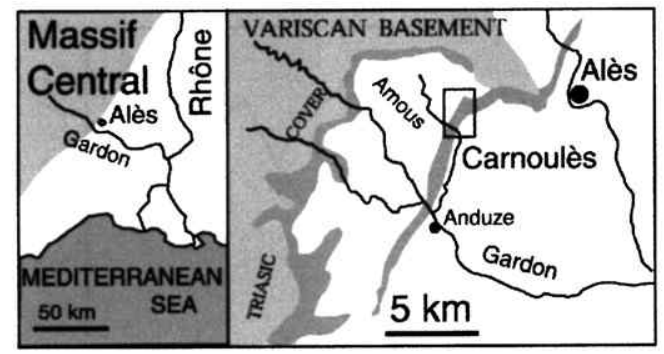

(a)

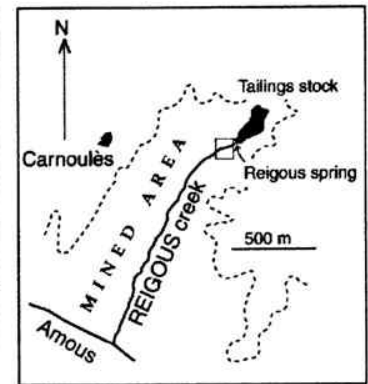

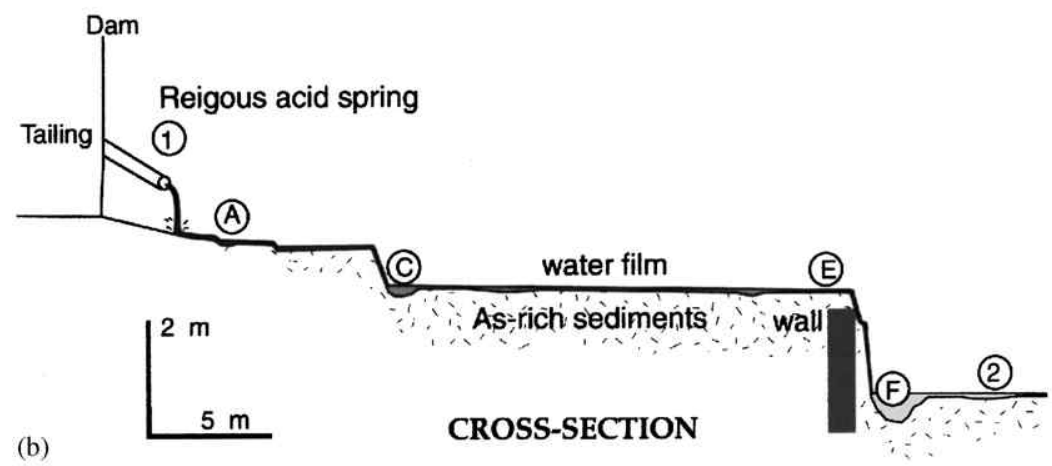

Fig. 1. (a) Location and geology of the studied area and (b) cross-section showing the location of the sampling stations (1, A, C, $\mathrm{E}, \mathrm{F}, 2)$. The transit time of water between stations 1 and 2 is about $1 \mathrm{~h}$. 
analysis. The samples for $\mathrm{Fe}$ and $\mathrm{As}$ speciation and sulfate determination were stored in the dark and analyzed within $24 \mathrm{~h}$.

The analysis of total dissolved As was performed by Inductively Coupled Plasma-Mass Spectrometry (ICPMS). The elevated As concentrations necessitated a dilution factor of 1000, and no interference due to $\mathrm{ArCl}$ was detected. Calibration of the ICP-MS was done by calibrating peak intensity, acquired in peak jump mode, with standard solutions. ${ }^{115}$ In was used as internal standard to correct for changes in peak intensities due to instrumental drift.

For the determination of dissolved As(III), the $\mathrm{pH}$ was adjusted to 4.8 using an acetic acid-sodium acetate buffer. Arsenite was determined using a hydride generation system coupled to the ICP-MS after reaction of As(III) with sodium borohydride. This method is similar to that described by Seyler and Martin [21], but has been modified according to Branch et al. [22]. The detection limit is $1 \mathrm{nM}$ and the precision better than $5 \%$. As $(V)$ was calculated as the difference between total dissolved As and As(III).

For $\mathrm{Fe}(\mathrm{II})$ determinations, filtered samples were buffered to $\mathrm{pH} 4.5$ with an ammonium acetate/acetic acid buffer in the field, and Fe(II) was complexed by adding $1 \mathrm{ml}$ of a $0.5 \%$ (w/w) 1,10-phenanthrolinium chloride solution to $10 \mathrm{ml}$ of sample [23]. Analyses were made by colorimetry at $510 \mathrm{~nm}$. The detection limit is $0.2 \mathrm{mM}$ and the precision better than $5 \%$. Total Fe (dissolved and colloidal) was determined by Flame Atomic Absorption Spectrometry.

\subsection{Kinetic studies}

Two kinds of ex situ experiments have been carried out. For each experiment, $100 \mathrm{ml}$ of freshly sampled raw spring water from the Reigous creek (containing free bacteria cells) were incubated for $150 \mathrm{~h}$ at room temperature. The agitation was maintained during the experiment in order to favor oxygenation. Control samples with spring water sterilized by filtration through $0.45 \mu \mathrm{m}$ Millipore filters and addition of formaldehyde $(0.5 \% \mathrm{v} / \mathrm{v})$, were run in the same conditions. Subsamples $(1 \mathrm{ml})$ were taken at regular time intervals (approximately $12 \mathrm{~h}$ ) and filtered using disposable in-line $0.45 \mu \mathrm{m}$ pore size filters and analyzed for As(III), total As, Fe(II) and total $\mathrm{Fe}$ as described above. The raw spring water and the control were incubated both in the dark and under a UV-lamp.

The second experiment was carried out in the presence of a bacteria-rich precipitate which forms spontaneously on the walls of a container filled with Reigous spring water. The precipitate was formed from the spring water incubated in flasks during 5 days. After this time, the water used for the formation of the precipitate was discarded and replaced by freshly sampled spring water.
It was then incubated in the dark and under a UV lamp in order to ensure that As oxidation is not related to the photochemical oxidation of As(III) by Fe described by Emett and Khoe [24].

\subsection{Bioassay to test arsenite and iron oxidation}

The bacteria present in the Reigous spring water were cultured in two different media. The first, an R2A medium (Difco laboratory) was used for organoheterotrophic bacteria [25]. The second, a 100:10 medium devoid of organic matter for the culture of lithotrophic bacteria. This medium, which is acid $(\mathrm{pH}$ 3.5 ), contains thiosulfate and iron and is recommended for the culture of acidophilic bacteria such as Acidithiobacillus ferrooxidans [26].

Three morphologically different colonies corresponding to bacterial strains B1, B2, B3 were isolated by three successive streaking on the R2A medium. Strains B4, B5 and B6 were isolated in the same way from the 100:10 thiosulfate medium.

For the oxidation assay, filter-sterilized spring water $(100 \mathrm{ml})$ was inoculated with $0.1 \mathrm{ml}$ of a pure strain of bacterial suspension $\left(10^{6}\right.$ cells $\left.\mathrm{ml}^{-1}\right)$. After an incubation period of 8 days at $30^{\circ} \mathrm{C}$ under continuous shaking, the samples were filtered on $0.45 \mu \mathrm{m}$ pore size filters. The speciation of As and $\mathrm{Fe}$ and their total concentrations in the aqueous phase were determined.

\section{Results}

\subsection{Aqueous chemistry}

The discharge of the Reigous spring varies between 0.2 and $1.3 \mathrm{l} / \mathrm{s}$, reflecting the wet and dry periods (Fig. 2a). The temperature varies over a 1-year period from $13.2^{\circ} \mathrm{C}$ to $16.5^{\circ} \mathrm{C}$ and the $\mathrm{pH}$, from 2.73 to 3.37 (Fig. 2b). The $\mathrm{O}_{2}$ content is $\geqslant 6 \mu \mathrm{M}$ during the wet season and $\leqslant 3 \mu \mathrm{M}$ during the dry season (Fig. 2b), depending on the variable rainwater input. Dissolved As and $\mathrm{Fe}$ concentrations (Fig. 2c) also vary in a large range with higher values during the dry season. The main species are As(III) and Fe(II), corroborating the previous findings of Michard and Faucherre [19]. Whereas $\mathrm{Fe}(\mathrm{III})$ is totally absent, variable amounts of As(V), between $0 \%$ and $40 \%$ of total As, have been recorded during three surveys (Table 1).

Whatever the initial $\mathrm{O}_{2}$ content of the spring water, $\mathrm{O}_{2}$ concentrations increase systematically abruptly between locations 1 and A (Fig. 3) and reach values higher than $125 \mu \mathrm{moll}^{-1}$ over a distance of $10 \mathrm{~m}$.

$\mathrm{Fe}(\mathrm{II})$ and $\mathrm{As}$ (III) concentrations decrease downstream (Fig. 3) and are strongly correlated $\left(0.87 \leqslant r^{2} \leqslant 0.99\right)$. The rate of $\mathrm{Fe}(\mathrm{II})$ and $\mathrm{As}(\mathrm{III})$ removal from the spring down to the wall (location E) located at 

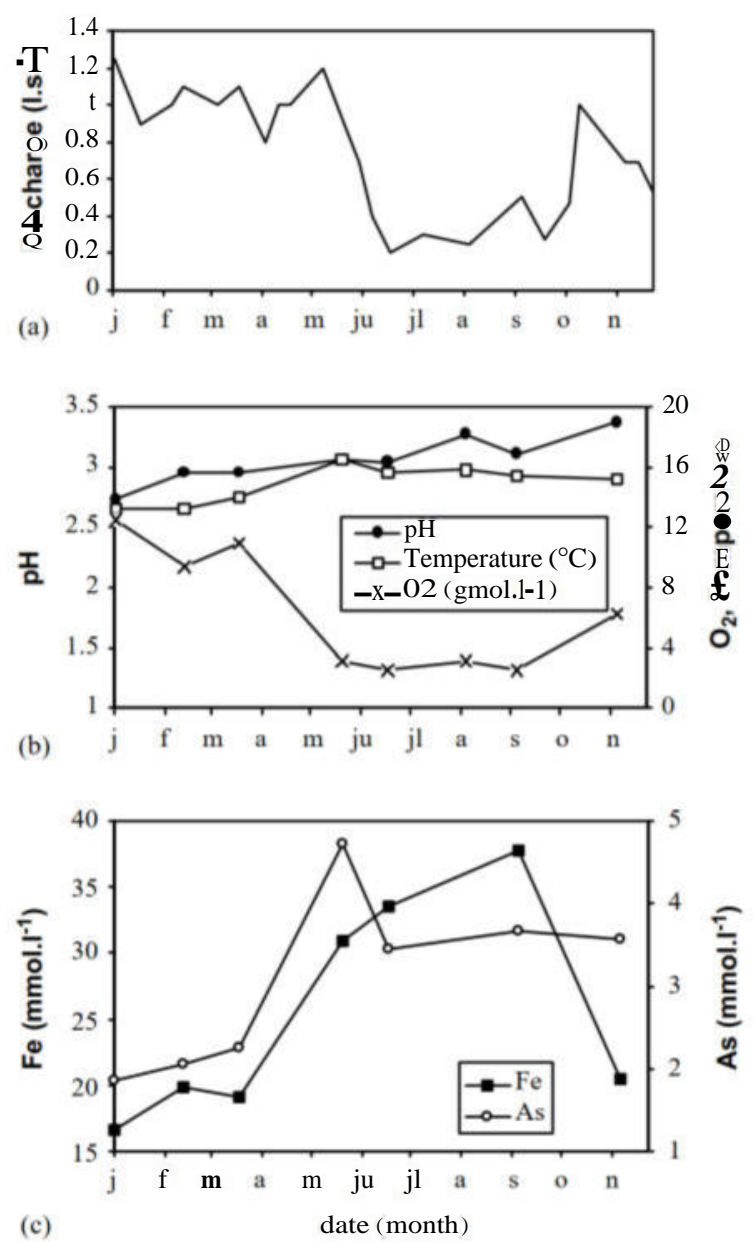

Fig. 2. Variations of discharge (a), $\mathrm{pH}, 02$ and temperature (b), dissolved As and $\mathrm{Fe}$ (c) of the Reigous spring (station 1) over the year 2001 .

$30 \mathrm{~m}$ varies seasonally (Fig. 3). During the wet season, $\mathrm{Fe}$ and As concentrations decrease immediately at the water outlet. During the dry season, the removal of the two elements is minor until the wall. Downstream from the wall, the Fe and As concentrations drop systematically.

\subsection{Role of bacteria in As and Fe removal and oxidation}

In the absence of bacteria, the amount of $\mathrm{As}$ and $\mathrm{Fe}$ removed from the solution is small $(22 \%$ and $3 \%)$ after 8 days (sample SA, Fig. 4).

More interestingly, the results indicate that three bacterial strains B2. B3, B6, play a significant role in Asor Fe-oxidation. Based on 16S rDNA sequence, B2 and B3 have the characteristics of the Thiomonas ynysl ([27], pers. comm.). These strains favor largely As oxidation and within the duration of the experiment, all the As in the dissolved phase has been oxidized (Fig. 4). B1, B2,
B3, B4 and B5 have little or no influence on Fe, only B6 favors Fe-oxidation and thus its precipitation and decreasing $\mathrm{Fe}(\mathrm{II})$ values in solution. However, B1, B4, B5 and B6 are not identified yet. The occurrence of $\mathrm{As}(\mathrm{V})$ in the aqueous phase suggests that B6 also catalyzes the oxidation of As whose major part coprecipitates with $\mathrm{Fe}(\mathrm{III})$.

\subsection{Kinetic studies}

When bacteria arc present as free living cells. $75 \%$ of As and $13 \%$ of $\mathrm{Fe}$ are removed within $150 \mathrm{~h}$ while no removal occurred in the absence of bacteria. The removal rates increase 2-fold for As and 10-fold for $\mathrm{Fe}$ in the presence of bacteria-rich precipitates (Fig. 5). Unlike Emett and Khoe [24] and Hug et al. [28], the UV experiments do not reveal an influence of photochemistry on As oxidation rate and its subsequent precipitation with Fe. In fact, the photochemical influence is negligible compared to that of bacteria.

\section{Discussion}

The removal of $\mathrm{Fe}$ in the upper part of the Reigous creek varies seasonally. The highest removal rate $\left(0.26 \mathrm{mmol}^{-1} \mathrm{~min}^{-1}\right)$ is reached during winter. It results from the oxidation of $\mathrm{Fe}(\mathrm{II})$ by iron oxidizing bacteria such as the strain B6. Such a process had been known for a long time in acid $\mathrm{Fe}^{2+}$ and $\mathrm{SO}^{-}{ }^{-}$-rich waters and was related to the activity of Acidithiobacillus ferrooxidems which are common in acid mine drainage [29]. In the first $12 \mathrm{~m}$ of the creek, the Fe removal is correlated $(\mathrm{r}=0.85)$ with the 02 content in spring water (Fig. 6) which depends on the meteoric conditions. During the wet season, the oxygen content of spring water at the outlet of the draining pipe is high enough to promote immediately the activity of iron oxidizing bacteria and the rate of Fe removal in the creek increases. During the dry season, the spring water at the drain outlet is nearly anoxic. The activity of aerobic Fe oxidizing bacteria seems to be inhibited in the first $12 \mathrm{~m}$. The rate of oxidation becomes slower and the $\mathrm{Fe}$ removal is negligible (Fig. 3).

The rate of $\mathrm{Fe}$ removal in the kinetic experiments is increased by the presence of a bacteria-rich precipitate, indicating that fixed bacteria are more efficient than free bacteria. However, the ex situ rates are always slower $\left(0.004 \mathrm{mmol} \mathrm{I}^{-1} \mathrm{~min}^{-1}\right)$ than the rates observed in the field, where Fe removal occurs in $30 \mathrm{~m}$ or after about $1 \mathrm{~h}$ of water flushing time. This suggests that the surface of the bacteria-rich precipitates relative to the surface of water, higher in the field, increases the rate of Feoxidation reaction.

The removal of As is associated with that of $\mathrm{Fe}$, as indicated by the correlation between the two elements in 
Table 1

Chemical analysis of the aqueous phase

\begin{tabular}{|c|c|c|c|c|c|c|c|c|c|c|}
\hline Station & Date & $d$ & $T$ & $\mathrm{pH}$ & $\mathrm{O}_{2}$ & $\mathrm{SO}_{4}^{2-}$ & As III & As V & As $T$ & $\mathrm{Fe} \mathrm{II}^{\mathrm{a}}$ \\
\hline & $10 / 01 /$ & & & & & & & & & \\
\hline 1 & & 0 & 13.2 & 2.73 & 13 & nd & 1.10 & 0.76 & 1.86 & 16.6 \\
\hline A & & 2 & 13.2 & 2.86 & 94 & nd & 0.89 & 0.20 & 1.09 & 14.1 \\
\hline $\mathrm{C}$ & & 12 & 12.7 & 2.97 & 125 & nd & 0.71 & 0.03 & 0.75 & 11.6 \\
\hline $\mathrm{E}$ & & 30 & 12.5 & 3.04 & 156 & nd & 0.66 & 0.00 & 0.66 & 10.9 \\
\hline $\mathrm{F}$ & & 32 & 12.3 & 3.03 & 156 & nd & 0.64 & 0.17 & 0.81 & 10.1 \\
\hline \multirow[t]{2}{*}{2} & & 38 & 12.3 & 3 & 156 & nd & 0.69 & 0.27 & 0.96 & 10.0 \\
\hline & $21 / 02 /$ & & & & & & & & & \\
\hline 1 & & 0 & 13.2 & 2.95 & 9 & 39 & 2.06 & nd & 2.06 & 19.9 \\
\hline A & & 2 & 12.8 & 3.1 & 63 & nd & 1.78 & nd & 1.78 & 18.1 \\
\hline $\mathrm{C}$ & & 12 & 12 & 3.05 & 125 & nd & 1.72 & nd & 1.72 & 15.8 \\
\hline E & & 30 & 11.4 & 3.1 & 172 & nd & 1.57 & nd & 1.57 & 14.9 \\
\hline $\mathrm{F}$ & & 32 & 11 & 3.1 & 188 & nd & 1.47 & nd & 1.47 & 13.7 \\
\hline \multirow[t]{2}{*}{2} & & 38 & 11.1 & 3.11 & 188 & 30 & 1.53 & nd & 1.53 & 15.2 \\
\hline & $27 / 03 /$ & & & & & & & & & \\
\hline 1 & & 0 & 14 & 2.95 & 11 & 31 & 2.14 & 0.12 & 2.26 & 19.1 \\
\hline A & & 2 & 13.7 & 3.15 & 47 & 26 & 1.78 & 0.29 & 2.08 & 15.6 \\
\hline $\mathrm{C}$ & & 12 & 13.9 & 3.18 & 125 & 27 & nd & nd & nd & 14.0 \\
\hline E & & 30 & 13.8 & 3.24 & 141 & 26 & 1.22 & 0.49 & 1.70 & 12.8 \\
\hline $\mathrm{F}$ & & 32 & 13.7 & 3.22 & 141 & 22 & 0.99 & 0.34 & 1.32 & 11.7 \\
\hline \multirow[t]{2}{*}{2} & & 38 & 14 & 3.3 & 156 & 25 & 1.09 & 0.57 & 1.66 & 12.5 \\
\hline & $29 / 05 /$ & & & & & & & & & \\
\hline 1 & & 0 & 16.5 & 3.06 & $\mathrm{DL}$ & 36 & 3.49 & 1.23 & 4.72 & 31.0 \\
\hline A & & 2 & 17 & 3.03 & 63 & 37 & 3.48 & 0.69 & 4.16 & 30.6 \\
\hline $\mathrm{C}$ & & 12 & 16.7 & 3.03 & 125 & 34 & 3.47 & 0.58 & 4.05 & 30.5 \\
\hline E & & 30 & 20 & 3.07 & 172 & 31 & 3.25 & 0.58 & 3.83 & 30.2 \\
\hline $\mathrm{F}$ & & 32 & 20.2 & 3.05 & 109 & 39 & 2.92 & 0.49 & 3.41 & 27.5 \\
\hline \multirow[t]{2}{*}{2} & & 38 & 21.5 & 3.04 & 156 & 34 & 2.97 & 1.41 & 4.39 & 27.2 \\
\hline & $26 / 06 /$ & & & & & & & & & \\
\hline 1 & & 0 & 15.6 & 3.04 & $\mathrm{DL}$ & 30 & 3.45 & nd & 3.45 & 33.5 \\
\hline A & & 2 & 16.3 & 3 & 109 & 27 & 3.55 & nd & 3.55 & 33.2 \\
\hline $\mathrm{C}$ & & 12 & 17 & 2.99 & 156 & 29 & 3.45 & nd & 3.45 & 31.0 \\
\hline $\mathrm{E}$ & & 30 & 20.6 & 3.04 & 172 & 28 & 3.20 & nd & 3.20 & 31.1 \\
\hline $\mathrm{F}$ & & 32 & 21.2 & 3.05 & 188 & 30 & 2.70 & nd & 2.70 & 27.1 \\
\hline 2 & & 38 & 22.3 & 3.02 & 172 & 29 & 2.85 & nd & 2.85 & 26.7 \\
\hline
\end{tabular}

$13 / 08 / 01$

\begin{tabular}{|c|c|c|c|c|c|c|c|c|c|}
\hline & & & & & & & & & \\
\hline 1 & 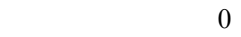 & 15.8 & 3.27 & DL & nd & 3.67 & nd & 3.67 & nd \\
\hline A & 2 & 17.2 & 3.18 & 125 & nd & 3.74 & nd & 3.74 & nd \\
\hline $\mathrm{C}$ & 12 & 17.4 & 3.17 & 156 & nd & 3.57 & nd & 3.57 & nd \\
\hline E & 30 & 19.7 & 3.18 & 172 & nd & 3.22 & nd & 3.22 & nd \\
\hline $\mathrm{F}$ & 32 & 19.5 & 3.13 & 156 & nd & 2.72 & nd & 2.72 & nd \\
\hline 2 & 38 & 20.8 & 3.14 & 188 & nd & 2.70 & nd & 2.70 & nd \\
\hline & $13 / 09 / 01$ & & & & & & & & \\
\hline 1 & 0 & 15.4 & 3.11 & DL & 57 & 3.39 & 0.19 & 3.57 & 37.8 \\
\hline A & 2 & 15.3 & 3.12 & 94 & 56 & 3.39 & nd & 3.27 & 35.2 \\
\hline $\mathrm{C}$ & 12 & 15.3 & 3.04 & 147 & 56 & 3.31 & nd & 3.20 & 34.9 \\
\hline $\mathrm{E}$ & 30 & 14.6 & 3.06 & 141 & 54 & 3.03 & nd & 3.00 & 34.2 \\
\hline $\mathrm{F}$ & 32 & 14.9 & 3.06 & 109 & 51 & 2.83 & nd & 2.77 & 32.3 \\
\hline 2 & 38 & 15.3 & 3.05 & 125 & 51 & 2.61 & nd & 2.59 & 30.5 \\
\hline
\end{tabular}


Table 1 (continued)

\begin{tabular}{|c|c|c|c|c|c|c|c|c|c|c|}
\hline Station & Date & $d$ & $T$ & $\mathrm{pH}$ & $\mathrm{O}_{2}$ & sol ${ }^{-}$ & As III & As $V$ & As $T$ & $\mathrm{Fe} 11^{\prime \prime}$ \\
\hline & 141111 & & & & & & & & & \\
\hline 1 & & 0 & 15.2 & 3.37 & 6 & 24 & 2.15 & 0.20 & 2.34 & 20.5 \\
\hline A & & 2 & 15 & 3.38 & 94 & 15 & 2.04 & 0.32 & 2.37 & 21.3 \\
\hline $\mathrm{C}$ & & 12 & 14.6 & 3.33 & 156 & 30 & 1.97 & 0.36 & 2.32 & 20.7 \\
\hline $\mathrm{E}$ & & 30 & 13.6 & 3.3 & 188 & 27 & 1.77 & 0.34 & 2.12 & 19.4 \\
\hline $\mathrm{F}$ & & 32 & 13.3 & 3.23 & 172 & 25 & 1.59 & 0.28 & 1.87 & 18.1 \\
\hline 2 & & 38 & 13 & 3.25 & 188 & 20 & 1.60 & 0.28 & 1.88 & 18.2 \\
\hline
\end{tabular}

Note: Ail concentrations are in $\mathrm{mmoll}^{-} \backslash$ except $\mathrm{CF}$ in $\mathrm{p} \mathrm{mol}^{-1} . d$. distance from the spring (meters); $T$, water temperature (degree Celsius); nd, not determined; DL. detection limit.

"Total Fe concentrations were identical to Fe II.
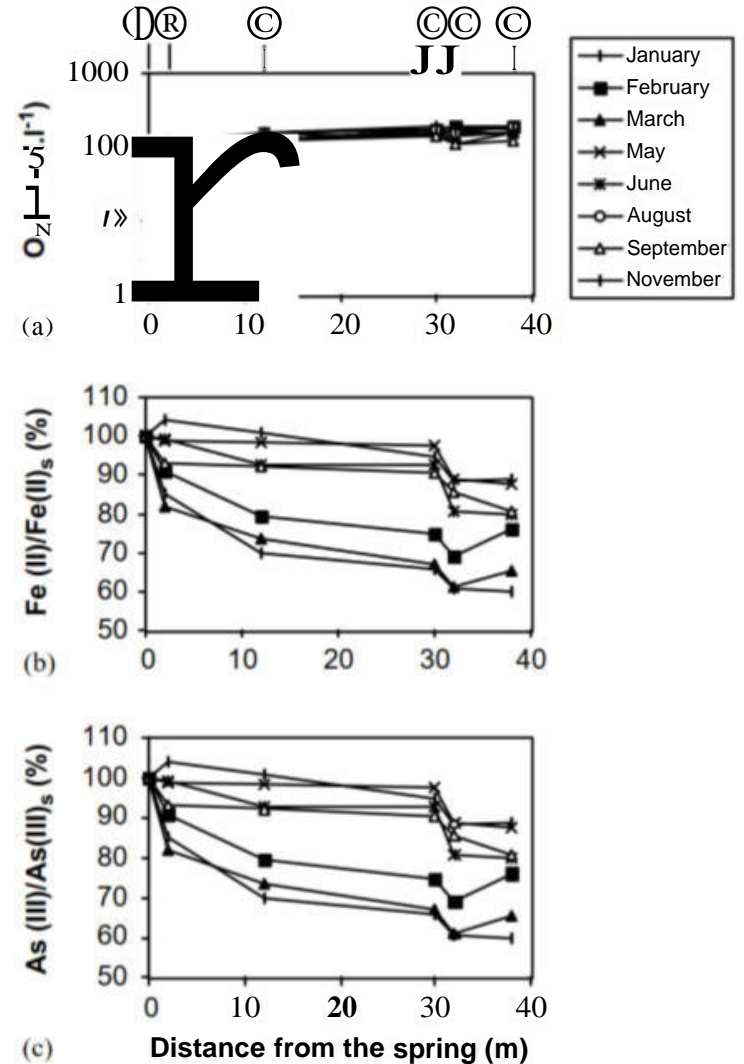

Fig. 3. Variation of CF (a), Fe(II) (b) and dissolved As(UI) (c) along the Reigous creek. Fe and As concentrations are expressed as a percentage of their concentration in spring water (suffix s). Total dissolved As varies as As(III). 1, A. C, E. F, 2: Sample locations (cf. Fig. lb).

each survey (Fig. 6), as well as by the ex situ experiments. The amount of As removed from the Reigous creek reaches up to $0.06 \mathrm{mmol} \mathrm{T}^{1} \mathrm{~min}^{-1}$ in the first $12 \mathrm{~m}$ and the $\mathrm{As} / \mathrm{Fe}$ ratio calculated from the amount of As and $\mathrm{Fe}$ removed from the aqueous phase ranges between 0.13 and 1.3. Such ratio reflects the formation of mixed $\mathrm{As}(\mathrm{V})-\mathrm{Fe}(\mathrm{III})$ precipitates which

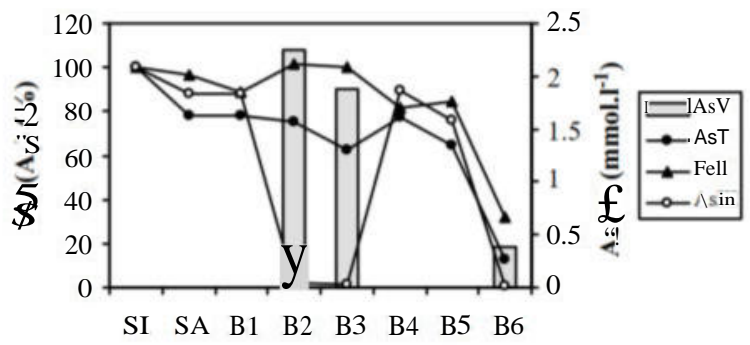

Fig. 4. Bioassay experiments: Oxidation of As and removal of Fc and As. The removal is expressed as the ratio $A / A u$ where $A$ is the concentration of $\mathrm{Fe}$ (II) or total dissolved As in the aqueous phase and $A_{0}$ is the concentration in the Carnoulès spring water before incubation (SI) with the following values in $\mathrm{nM}: 3.09$ for total dissolved As and As(III), 31 for Fe(II). SA is sterile spring water without any inoculation incubated 8 days. B1, B2, B3. B4, B5 and B6 are pure bacterial strains isolated from the Reigous spring water.

occurs in some As-rich AMD [7] rather than adsorption of As on Fe-oxyhydroxide. The scavenging of As by Fe is efficient because of the acid character of the water. Indeed, when the waters are alkaline [16], Fe precipitates without any effect on As distribution. But in some acid waters, where the removal of $\mathrm{Fe}$ is incipient. As is not scavenged and there is a build-up of $\mathrm{As}(\mathrm{V})$ in the aqueous phase [15]. When present in Reigous water, $\operatorname{As}(\mathrm{V})$ has been generated inside the tailings as indicated by its content at the outlet. Otherwise it is not evidenced from the analysis of creek water, but the bioassays clearly indicate the formation of $\mathrm{As}(\mathrm{V})$ in the presence of certain type of bacteria. The results suggest that the $\mathrm{As}(\mathrm{V})$ formed in the creek water is immediately scavenged by $\mathrm{Fe}(\mathrm{III})$. The decoupling of the decrease of $\mathrm{As}(\mathrm{III})$ and $\mathrm{Fe}(\mathrm{II})$ in the bioassays seems to indicate the existence of two separate As-oxidizing and Feoxidizing strains. The presence or absence of these strains may influence the mobility of arsenic. Asoxidizing strains such as Thiomonas sp. isolated from the Reigous Creek may be significantly involved in the natural attenuation of As; however, the efficiency of the 


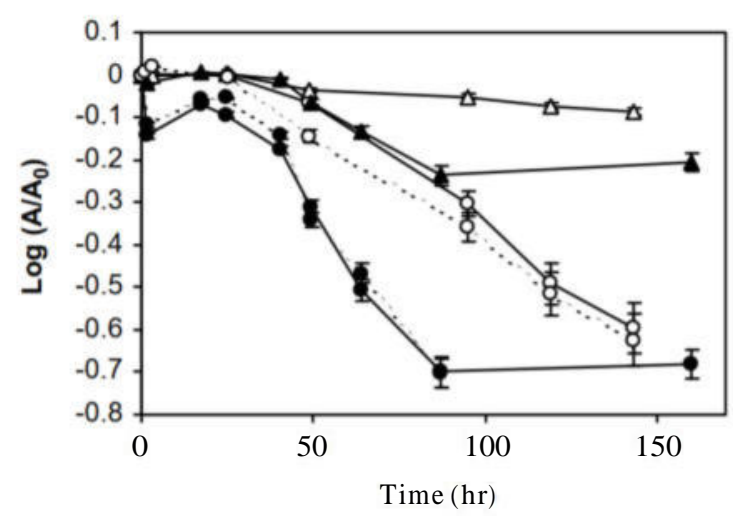

Fig. 5. Kinetics of Fe (triangles) and As removal (circles). Open symbol with free bacteria cells. Close symbols with a bacterial precipitate present (fixed bacteria). Continuous line for UVlight. dotted line for dark experiments. $A$ and $A n$ same as in Fig. 4.

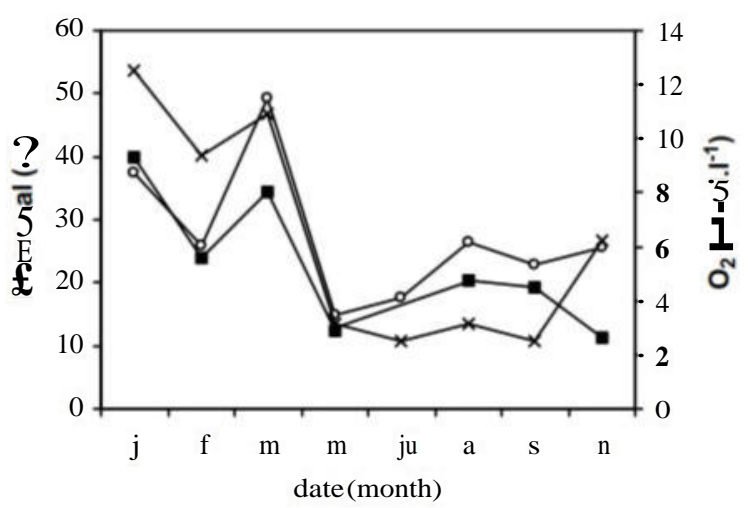

Fig. 6. Removal of Fe(II) (squares) and As(III) (circles) in the Reigous creek and $\mathrm{O}_{2}$ content (crosses) in spring water during a year (2001).

removal process seems to be related to the activity of $\mathrm{Fe}-$ oxidizing bacteria such as B6.

Further experiments are needed to know if As oxidation is the result of a detoxification pathway, or if it is used, instead of iron oxidation, for the fixation of inorganic carbon (chemolithoautotrophic growth).

\section{Conclusion}

Arsenic is precipitated very rapidly with $\mathrm{Fe}$ (III) during the flow of the Reigous acid creek. The rate of precipitation is seasonally variable, in relation to the oxygen content at the spring of the Reigous creek. The precipitation rate is related to iron oxidation and is therefore increased with iron-oxidizing bacteria such as B6, isolated from the creek. The presence of fixed bacteria in the precipitates which cover the bottom of the Reigous creek increases As- and Fe-removal rates compared to free bacterial cells. Rapid arsenic oxidation also occurs in the creek water due to the activity of Asoxidizing bacteria. Two strains isolated from the creek water and identified as Thomonas $s p$. have the ability to oxidize As(IlI).

\section{Acknowledgements}

This study was financed by the European project Piramid (contract EVK1-CT-1999-000021), the Programme Environment Vie et Société and GEOMEX (CNRS) and the ACI-Ecologic Quantitative (French Ministry of Research).

The authors are indebted to Claude Dupuy for his helpful comments on the manuscript.

\section{References}

[1] Amran MB, Hagège A. Lagarde F, Leroy MJF, Lamotte A. Demesmay C. Olle M. Albert M. Raurct G, LopczSanchez JF. Arsenic spéciation in environmental matrices. In: Quevauviller P. Maier EA, Grieink B. editors. Quality assurance for environmental analysis. Amsterdam: Elsevier. 1995. p. 285-304.

[2] Mok WM. Wai CM. Mobilization of arsenic in contaminated river waters. In: Nriagu $\mathbf{J}$, editor. Arsenic in the environment. Part I: cycling and characterization. New York: Wiley. 1994. p. 99-118.

[3] Maeda S. Biotransformation of arsenic in the freshwater environment. In: Nriagu JO, editor. Arsenic in the environment. Part I: cycling and characterization. New York: Wiley. 1994. p. 155-88.

[4] Francesconi KA, Edmonds JS. Biotransformation of arsenic in the marine environment. In: Nriagu JO, editor. Arsenic in the environment. Part I: cycling and characterization. New York: Wiley, 1994. p. 221-62.

[5] Williams M. Arsenic in mine waters: an international study. Environ Geol 2001;40(3):267-78.

[6] Daus B. Mattusch J, Paschke A, Wennrich R. Weiss H. Kinetics of the arsenite oxidation in seepage water from a tin mill tailings pond. Talanta 2000;51:1087-95.

[7] Carlson L. Bigham JM, Schwertmann U, Kyek A. Wagner F. Scavenging of As from acid mine drainage by schwertmannite and ferrihydrite: a comparison with synthetic analogues. Environ Sci Technol 2002;36:1712-9.

[8] Sadiq M. Arsenic chemistry in soils: an overview of thermodynamic predictions and field observations. Water Air Soil Pollut 1997:93:117-36.

[9] Manning BA. Fendorf SE. Goldberg S. Surface structures and stability of arsenic(III) on goethite: spectroscopic evidence for inner-sphere complexes. Environ Sci Technol 1998;32:2383-8.

[10] Oscarson DW. Huang PM, Defosse C, Herbillon A. Oxidative power of $\mathrm{Mn}(\mathrm{IV})$ and $\mathrm{Fe}$ (III) oxides with respect to $\mathrm{As}(\mathrm{Ul})$ in terrestrial and aquatic environments. Nature 1981:291:50-1. 
[11] Bowell RJ. Sorption of arsenic by iron oxides and oxyhydroxides in soils. Appl Geochem 1994;9:279-86.

[12] Cherry JA, Shaikh AU, Tallman DE, Nicholson RV. Arsenic species as an indicator of redox conditions in groundwater. J Hydrol 1979;43:373-92.

[13] Phillips SE, Taylor ML. Oxidation of arsenite to arsenate by Alcaligenes foecalis. Appl Environ Microbiol 1976;32: 393-9.

[14] Osborne FH, Ehrlich H. Oxidation of arsenite by a soil isolated of Alcaligenes. J Appl Bacteriol 1976;41:295-305.

[15] Langner HW, Jackson CR, Mcdermott TR, Inskeep WP. Rapid oxidation of arsenite in a hot spring ecosystem, Yellowstone National Park. Environ Sci Technol 2001; 35:3302-9.

[16] Gihring TM, Druschel GK, Mccleskey RB, Hamers RJ, Banfield JF. Rapid arsenite oxidation by Thermus aquaticus and Thermus thermophilus: field and laboratory investigations. Environ Sci Technol 2001;35:3857-62.

[17] Wakao N, Koyatsu H, Komai Y, Shimokawara H, Sakurai Y, Shiota H. Microbial oxidation of arsenite and occurrence of arsenite-oxidizing bacteria in acid mine water from a sulfur-pyrite mine. Geomicrobiol $\mathbf{J}$ 1988;6:11-24.

[18] Leblanc M, Achard B, Ben Othman D, Luck JM. Accumulation of arsenic from acidic mine waters by ferruginous bacterial accretions (stromatolites). Appl Geochem 1996;11:541-54.

[19] Michard G, Faucherre J. Etude géochimique de l'altération des minerais sulfurés de St. Sébastien d'Aigrefeuille. Chem Geol 1970;6:63-84.

[20] Leblanc M, Casiot C, Elbaz-Poulichet F, Personné C. Arsenic removal by oxidizing bacteria in a heavily arsenic contaminated acid mine drainage system (Carnoulès, France). Younger PL, Robins NS, editors. Mine water hydrogeology and geochemistry. Geological Society of London Special Publication, Kluwer Academic Publishers: Dordrecht, 2002. 464pp.

[21] Seyler P, Martin JM. Biogeochemical processes affecting arsenic species in a permanently stratified lake. Environ Sci Technol 1989;28:1258-63.

[22] Branch S, Corns W, Ebdon L, Hill S, O'Neill P. Determination of As by hydride generation inductively coupled plasma mass spectrometry using a tubular membrane gas-liquid separator. J Anal At Spectr 1991;6:155-8.

[23] Rodier J, Broutin JP, Chambon P, Champsaur H, Rodi L. L'analyse de l'eau. Paris: Dunod, 1996, 1383pp.

[24] Emett MT, Khoe GH. Photochemical oxidation of arsenic by oxygen and iron in acidic solutions. Water Res 2001;35(3):649-56.

[25] Reasoner DJ, Geldreich EE. A new medium for the enumeration and subculture of bacteria from potable water. Appl Environ Microbiol 1985;49:1-7.

[26] Schrader JA, Holmes DS. Phenotypic switching of Thiobacillus ferroxidans. J Bacteriol 1988;170(9):3915-23.

[27] Le Flèche, Grimont. Institut Pasteur. Laboratoire d'identification moléculaire. 25, rue du Dr. Roux. 75000 Paris, France, 2001.

[28] Hug SJ, Canonica L, Wegelin M, Gechter D, Von Gunten U. Solar oxidation and removal of arsenic at circumneutral $\mathrm{pH}$ in iron containing waters. Environ Sci Technol 2001;35:2114-21.

[29] Singer PC, Stumm W. Acid mine drainage: the rate determining step. Science 1970;167:1121-3. 